J. Perinat. Med.

3 (1975) 101

\section{Portal hypertension in children following neonatal umbilical disorders}

\author{
M. Obladen, D. Ernst, D. Feist, L. Wille \\ Universitäts-Kinderklinik Heidelberg \\ (Head: Prof. Dr. H. BickeL)
}

Received August 20, 1974. Accepted September 25, 1974.
Pre-hepatic portal vein obstruction is a rare condition in childhood. It was first described 50 years ago [15] and within the last ten years some cases have been ascribed to neonatal umbilical disorders $[4,8,14,20,24]$. The most important causes recognized today are described in Tab. I.

Tab. I. Causes of pre-hepatic portal vein obstruction.

\begin{tabular}{ll}
\hline I Congenital: & $\begin{array}{l}\text { Developmental anomaly } \\
\text { Irregularity of physiological umbilical } \\
\text { vein obliteration }\end{array}$ \\
II Acquired: & $\begin{array}{l}\text { Umbilical infection (sepsis, throm- } \\
\text { bosis) } \\
\text { Umbilical vein catheterization } \\
\text { Exchange transfusion }\end{array}$ \\
\hline
\end{tabular}

Since the development of neonatal intensive care, reports have increased describing iatrogenic lesions resulting from the increased use of indwelling catheters $[3,16,19,22,23]$. It has been found, for example, that the injection of potentially harmful solutions into a malpositioned catheter may result in severe vascular and tissue damage $[12,25]$. Several severe necroses were described following the injection of TнAм for treatment of acidosis $[9,13]$. A recent report by KeUth [10], who used X-rays for control of catheter placement, indicated correct positioning of the catheter in the vena cava in only $29 \%$ of cases. In $65 \%$ the catheter was situated in the portal vein sinus. Similar observations have been made by several other investigators $[2,11,18]$

\section{Curriculum vitae}

Michael Obladen, born July 21, 1944. High scbool at Mannbeim, studies of Medicine and Pbilosopby at the Universities of Würburg, Frankfurt, and Heidelberg 1963-1969. State examination and $M D$ graduation 1969. Assistent at Heidelberg University Cbildren's Hospital since October 1970. Specialization in pediatric intensive care since 1972.

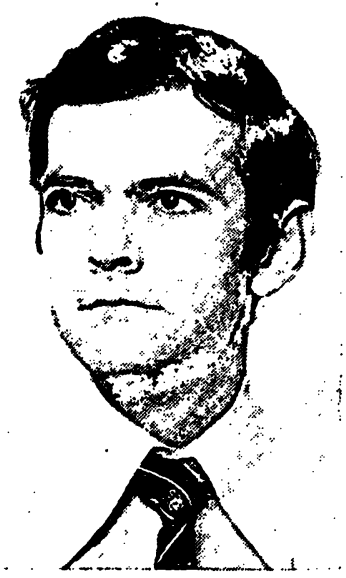

and correlate with our experience. Most recently RoLOFF indicated that in his study $50 \%$ of the catheters were in the portal vein system [17]. In his group 8 prematures who had previously been treated via umbilical catheterization developed partial or total portal vein thrombosis. Four of these children suffered from massive bleeding from esophageal varices. Recently, we treated 10 children with prehepatic portal vein obstruction. In order to evaluate the etiology of the disease, we reviewed their birth history.

\section{Subjects and methods}

Ten patients with pre-hepatic portal vein stenosis have been recognized during the years 1968 to 1974. Six of them were boys, four were girls, the age at the time of diagnosis ranging from 3 months to 6 years 2 months. Seven children had esophageal hemorrhages, in three of which 
massive hemorrhage led to the diagnosis. The youngest child with esophageal bleeding was 17 months old. In four children transthoracic ligature had to be performed for treatment of massive hemorrhage, one other child died from massive bleeding before an operation could be performed. The primary sign suggesting this disorder in the other children was isolated splenomegaly without liver enlargement, often accompanied by abdominal distention or recurrent abdominal pain. Splenomegaly usually was found during the second or third year of life. The esophagograms of 8 children showed wide spread esophageal varices. In all cases the diagnosis was confirmed by splenic venography. Histological examination of the liver revealed a slight fibrosis in 7 cases, possibly due to a septic hepatitis in the neonatal period. The perinatal history of the ten children was studied.

\section{Results}

All children with portal vein obstruction had complicated birth histories and all had been in hospital care during their neonatal period. The pathologic findings are summarized in Tab. II.

In five patients an umbilical infection shortly after birth is presumed to be the cause of the portal vein obstruction. One premature who had severe birth asphyxia and a respiratory distress syndrome may have acquired the portal bed block as a result of the injection of THAM into the umbilical vein catheter. Another premature, also suffering from RDS, had an exchange transfusion for hyperbilirubinemia by an umbilical catheter. In all other children, no umbilical vessel catheterization had been performed. Three newborns were hospitalized for nonumbilical diseases.

\section{Discussion}

No exact information is available describing the relative frequency of extra-hepatic portal vein obstruction following neonatal umbilical disorders. The few prospective studies developed to answer this question are not statistically reliable because of small sample size due to the rarity of the disease. Thompson [23] reviewed 493 cases after exchange transfusions and 86 children after umbilical sepsis and never found a case of portal vein stenosis, nor did Devens [5] after a reexamination of 202 children who had exchange transfusions during their neonatal period. ERKAN described one case of extra-hepatic portal vein occlusion when reexamining 155 children who had survived treatment with indwelling catheters for long-term infusions through the umbilical vein in the neonatal period [7]. The association between portal vein stenosis and

Tab. II. Perinatal complications in children developing extrahepatic portal obstruction.

\begin{tabular}{|c|c|c|c|c|c|}
\hline \multicolumn{2}{|c|}{$\begin{array}{l}\text { Patient } \\
\text { Nr./Sex }\end{array}$} & Birth anomaly & $\begin{array}{l}\text { Cause for hospitalization } \\
\text { in newborn period }\end{array}$ & \multirow[t]{2}{*}{$\begin{array}{l}\text { Umbilical } \\
\text { catheter }\end{array}$} & \multirow{2}{*}{$\frac{\begin{array}{c}\text { Age at } \\
\text { diagnosis of } \\
\text { splenomegaly }\end{array}}{1 \text { y } 5 \text { mo }}$} \\
\hline 1. B. C. & 우 & Premature infant, $1230 \mathrm{~g}$ & $\begin{array}{l}\text { Respiratory distress syndrome } \\
\text { Exchange transfusion }\end{array}$ & & \\
\hline 2. C. D. & $\hat{o}$ & Premature twin, asphyxia & $\begin{array}{l}\text { Respiratory distress syndrome } \\
\text { Umbilical vein catheter with } \\
\text { TRIS-buffer injection }\end{array}$ & + & $1 \mathrm{y} 1 \mathrm{mo}$ \\
\hline 3. O. K. & $\tilde{\sigma}$ & Section, placenta previa & Umbilical infection & - & $2 \mathrm{y} 5 \mathrm{mo}$ \\
\hline 4. U. G. & 우 & Coiling of the cord & Umbilical sepsis & - & $2 \mathrm{y} 5 \mathrm{mo}$ \\
\hline 5. B. H. & $\tilde{\sigma}$ & Section, small-for-date & Umbilical infection & - & 6 y $2 \mathrm{mo}$ \\
\hline 6. S.P. & 우 & $\begin{array}{l}\text { Breech presentation, prolonged } \\
\text { labor }\end{array}$ & Umbilical sepsis & - & 3 y $10 \mathrm{mo}$ \\
\hline 7. A. G. & $\pi$ & Forceps, aspiration & Sepsis, osteomyelitis & - & 2 y $11 \mathrm{mo}$ \\
\hline 8. G.S. & o & Section, breech present. & Feeding difficulties & - & $1 \mathrm{y} 6 \mathrm{mo}$ \\
\hline 9. A. M. & $\hat{\sigma}$ & Asphyxia & Ventricular septum defect & - & $1 \mathrm{y} 2 \mathrm{mo}$ \\
\hline 10. H. D. & $\overline{0}$ & $\begin{array}{l}\text { Transverse presentation, } \\
\text { early rupture of membranes, } \\
\text { section }\end{array}$ & Anemia & - & $3 \mathrm{mo}$ \\
\hline
\end{tabular}


neonatal umbilical complications has generally been accepted. Only Auvert [1] and Dolecki [6] suggest that the condition is primarily due to an inborn developmental anomaly.

\section{Conclusions}

Portal vein obstruction in childhood has a poor prognosis because of the frequency of esophageal varices and subsequent hemorrhage. The following suggestions may be helpful in preventing this iatrogenic disorder:

1. In birth asphyxia the peripheral umbilical cord should be cannulated and an umbilical catheter avoided whenever possible for in- jections of potentially sclerosing solutions. An injection should never occur into the peripheral umbilical artery.

2. Na-Bicarbonate appears to be less sclerosing to the vascular wall than THAM. Buffer solutions should be thoroughly diluted and injected slowly in all instances.

3. Long-term infusions through an umbilical catheter should be performed only in extreme cases when no other route is available. The position of each catheter must be checked by $\mathrm{X}$-ray immediately after insertion.

4. Reexamination of at-risk children in the 2 nd year of life can often establish the diagnosis before an esophageal hemorrhage has occured.

\section{Summary}

10 children presented pre-hepatic portal vein obstruction during their first 6 years of life. 8 of them had massive esophageal varices, 1 died from acute esophageal hemorrhage. The perinatal history of these children was studied (Tab. II): All of them had an abnormal birth history and all had been hospitalized during their neonatal period. In

5 of them an umbilical infection had been diagnosed, one had an injection of THAM and one other an exchange transfusion through an umbilical vein catheter.

Pre-hepatic portal vein occlusion in children is presumed to be mainly an acquired disease resulting from neonatal umbilical disorders.

Keywords: Newborn infant, premature infant, portal hypertension, splenoportography, vena portae, umbilical infection, umbilical catheter.

\section{Zusammenfassung}

Portale Hypertension bei Kindern nach neonatalen Nabelprozessen

Geburt und Neugeborenenperiode von 10 Kindern werden dargestellt, welche während der ersten 6 Lebensjahre eine prähepatische Pfortaderstenose entwickelten. 8 Kinder hatten ausgedehnte Ösophagusvarizen, eines starb an einer massiven Ösophagusvarizenblutung. Alle Kinder hatten eine aufällige Geburtsanamnese und alle waren während der Neugeborenenperiode in stationärer Behandlung (Tab. II): In 5 Fällen war eine Nabelinfektion diagnostiziert worden, in je einem Fall war eine TRIS-Puffer-Injektion bzw. eine Austausch-Transfusion durch einen Nabelvenenkatheter erfolgt.

Es wird angenommen, daß die prähepatische Pfortaderstenose im wesentlichen eine erworbene Krankheit ist, die nach neonatalen Nabelprozessen entsteht.

Schlüsselwörter: Nabelkatheter, Nabelinfektion, Neugeborenes, portale Hypertension, Prämaturität, Splenoportographie, Vena porta.

\section{Résumé}

Hypertension portale chez les enfants, consécutive à des troubles ombilicaux néonataux

Cet article traite de l'étude natale et post-natale de 10 enfants ayant présenté une occlusion de la veine porte préhépatique au cours de leurs six premières années. On a observé chez 8 d'entre eux des varices oesophagiennes massives et enregistré 1 décès à la suite d'une hémorragie oesophagienne aigue.

Chez tous les enfants on a relevé une anamnèse natale anormale et une hospitalisation en période néonatale
(Tab. II), avec 5 diagnostics d'infection ombilicale, une injection de Tham et rune transfusion de substitution par cathéter de la veine ombilicale.

On présume que l'occlusion de la veine porte préhépatique chez les enfants est essentiellement une maladie acquise, résultant de troubles ombilicaux néonataux.

Mots-clés: Cathéter ombilical, enfant nouveau-né, hypertension portale, infection ombilicale, prématurité, splenoportographie, veine porte. 


\section{Bibliography}

[1] Auvert, J., C. FArge: Portal hypertension in children in a series of 132 cases. Ann. Chir. 17 (1963) 281

[2] Baker, D. H., W. E. Berdon, L. S. James: Proper lecalization of umbilical arterial and venous catheters by lateral roentgenograms. Pediatrics 43 (1969) 34

[3] Buttenberg, H., R. Walch: Pfortaderthrombose als Folge wiederholter Austauschtransfusionen über verweilenden Nabelvenenkatheter. Mschr. Kinderheilk. 116 (1968) 33

[4] Clatworthy, H. W., E. T. Boles: Extrahepatic portal bed block in children: pathogenesis and treatment. Ann. Surg. 150 (1959) 371

[5] Devens, K., H. Fended, D. Meister: Die Ätiologie der extrahepatisch bedingten portalen Hypertension beim Kind. Z. Kinderchir. 7 (1969) 458

[6] Doleckij, S. J., V. G. Akopjan: Portale Hypertension bei Kindern. Pathogenese und Behandlung. Hippokrates, Stuttgart 1973

[7] ERkan, V., W. Blankenship, M. T. Stahlman: The complications of chronic umbilical vessel catheterization. Pediat. Res. 2 (1968) 317

[8] Ewerbeck, H.: Über den Pfortaderhochdruck bei Kindern. Z. Kinderchir. 2 (1965) 441

[9] Heimig, E., H. Rehder: Organschäden nach TrisPuffer-Injektion in die Nabelgefäße. Deutsch. med. Wschr. 98 (1973) 305

[10] Keuth, U., C. Conter, J. Wilhelmr: Zur Position des Nabelvenenkatheters. Röntgenanalyse von 200 Fällen aus dem klinischen Routinebetrieb. Mschr. Kinderheilk. 120 (1972) 175

[11] Kitterman, J. A., R. H. Phibbs, W. H. Tooley: Catheterization of umbilical vessels in newborn infants. Pediatr. Clin. North. Amer. 17 (1970) 895

[12] Larroche, J. Cl.: Umbilical catheterization: its Complications. Anatomical Study. Biol. Neonate 16 (1970) 101

[13] Lawin, P., M. Telschow: Gewebeschäden durch paravenöse Tham-Infusion. Z. prakt. Anästh. Wiederbeleb. 4 (1966) 252
[14] Mahoney, E. B., L. Hogg: Congenital structure of the portal vein. Arch. Surg. 61 (1950) 713

[15] Oprrz, H.: Zur Kenntnis der thrombophlebitischen Splenomegalie. Jb. Kinderh. 107 (1924) 211

[16] Oski, F. A., D. M. Allen, L. K. Dlamond: Portal hypertension, a complication of umbilical vein catheterization. Pediatrics 31 (1963) 297

[17] Roloff, D., U. Hrrche, B. Pastor: Untersuchungen über Lage und anatomisch faßbare Komplikationen bei Nabelvenenkatheterisierung. Mschr. Kinderheilk. 121 (1973) 465

[18] Rosen, M. S., S. B. ReICH: Umbilical venous catheterization in the newborn: Identification of correct positioning. Radiology 95 (1970) 335

[19] Scort, J. M.: Iatrogenic lesion in babies following umbilical vein catheterization. Arch. Dis. Child. 40 (1968) 426

[20] Shaldon, S., S. Sherlock: Obstruction to the extrahepatic portal circulation in childhood. Lancet (1962) I, 63

[21] SHERLOCK, S.: Aetiology of portal hypertension in childhood. Proc. Roy. Soc. Med. 55 (1962) 768

[22] Tizard, J. P. M.: Portal hypertension following exchange transfusion through the umbilical vein. Proc. Roy. Soc. Med. 55 (1962) 772

[23] Thompson, E. N., S. Sherlock: The etiology of portal thrombosis with particular reference to the role of infection and exchange transfusion. Quart. J. Med. 33 (1964) 465

[24] Trusler, G. A., F. R. Morris, W. T. Mustard: Portal hypertension in childhood. Surgery 52 (1962) 664

[25] Wigger, H. J., B. R. Bransilver, W. A. Blanc: Thrombosis due to catheterization in infants and children. J. Pediat. 76 (1970) 1
Dr.: Michael Obladen
Universitäts-Kinderklinik
Hofmeisterweg 1-9
D-69 Heidelberg/Germany 